\title{
抗菌薬の皮膚反応テスト添付文書の比較検討
}

\author{
池田博昭, ${ }^{*}, a$ 佐藤英治, ${ }^{a}$ 横山 隆, ${ }^{b}$ 木村康浩, ${ }^{a}$ 木平健治 ${ }^{a}$
}

\section{Investigation of Package Inserts for Physicians in Skin Test Kits for Detecting Allergies to Antibiotic Agents in Japan}

\author{
Hiroaki IKEDA, ${ }^{*, a}$ Eiji SATO, ${ }^{a}$ Takashi YoKoYAmA, ${ }^{b}$ \\ Yasuhiro KIMURA, ${ }^{a}$ and Kenji KiHIRA ${ }^{a}$ \\ Department of Pharmaceutical Services, ${ }^{a}$ Hiroshima University Hospital, and Department \\ of General Medicine, ${ }^{b}$ School of Medicine, Hiroshima University, 1-2-3 \\ Kasumi, Minami-ku, Hiroshima 734-8551, Japan
}

(Received November 8, 2002; Accepted January 23, 2003)

\begin{abstract}
To avoid serious adverse reactions, especially anaphylactic shock, a skin test to detect allergy is recommended prior to the administration of antimicrobial drugs. Japanese pharmaceutical companies provide skin test kits appropriate for each drug, specifying how to administer and interpret the skin test in a package insert for physicians. However, procedures are not consistent between products. We therefore examined package inserts accompanying skin tests for allergies to antimicrobial drugs in use at the Hiroshima University Hospital, including five penicillin, 13 cephalosporin, and four carbapenem preparations. Preparation of test solutions followed five different protocols. Positive responses were defined by four different criteria, and three different intervals between inoculation and reading times were specified. Such differences in procedures between skin test kits appear likely to confuse physicians when using and interpreting the tests. These results suggest that standardization of skin tests would promote more rational and effective use of antimicrobial drugs.
\end{abstract}

Key words_— skin test; antimicrobial drugs; physician package inserts; positive response criteria; intervals to reading

\section{緒言}

抗菌薬の添付文書には, 重要な基本的注意事項と して「ショックが現れる恐れがあるので，十分な問 診を行うこと.なお，事前に皮膚反応を実施するこ とが望ましい.」と記載されている. そのため, 抗 菌薬の静脈内投与を行う際に, 微量の当該薬剤を含 む皮膚反応テス卜液を用いて皮内反応が行われてい る.1 このテストは, アレルギーによる副反応をで きうる限り予知し, 重篤な副作用の発現を避けるた めに行われている. 抗菌薬の中のセフェム系, ペニ シリン系及びカルバペネム系の先発品及び後発品を 含むすべての静注用製品は, 製造者より皮膚反応テ スト・キット（以後キットと省略）が供給されてい る.

その理由は, 昭和 31 年に医務局長より通知が行

a) 広島大学医学部附属病院薬剂部, b) 広島大学医学部附 属病院総合診療部

e-mail: ike@ hiroshima-u.ac.jp
われ，抗菌薬の使用前の注意として「問診，皮膚反 応テストを行うことが望ましい.」とされ, 添付文 書はこの通知に従っているのが原因と思われる. ${ }^{2}$ これらのことから，簡易的に皮膚反応テストを行う キットは，抗菌薬の製造者から製品とは別に無償で 供給されている場合が多い.

しかしながら，これら供給されている皮膚反応テ ストを行うキットは, 以前より, その調製法や判定 基準が抗菌薬の銘柄間で異なっている. そのため, 施用する医師が 2 種類以上の皮膚反応テストを行わ なければならない場合, 同時に行わなくともそのつ ど，キットに添付された文書を熟読する必要があ り, 施用に混乱を生じかねない状況が存在している.

さらにキットは, 薬価基準の収載対象外で, また 皮膚反応検査は健康保険の所定の点数を算定できな い業務であることから, その有用性, 経済性及び危 機管理を含めて業務を合理化する必要がある。しか しながらキットの現状を把握した報告は少ないのが 現状である. 
Table 1. Comparison of Volumes of Diluent and Control Solutions per Ampule between Skin Test Kits

\begin{tabular}{c|cc}
\hline \hline 溶解液 & 容 量 & 製品数 \\
\hline \multirow{2}{*}{ 生理食塩水 } & $1.0 \mathrm{ml}$ & 2 \\
& $1.3 \mathrm{ml}$ & 1 \\
& $2.0 \mathrm{ml}$ & 12 \\
\hline \multirow{2}{*}{ 注射用水 } & $1.0 \mathrm{ml}$ & 4 \\
\hline 専用溶解液 & $2.0 \mathrm{ml}$ & 1 \\
\hline
\end{tabular}

\begin{tabular}{c|cc}
\hline \hline 対照液 & 容 量 & 製品数 \\
\hline \multirow{3}{*}{ 生理食塩水 } & $1.0 \mathrm{ml}$ & 9 \\
& 溶解液*と兼用 & 12 \\
& $2.0 \mathrm{ml}$ & 3 \\
\hline
\end{tabular}

*: $2 \mathrm{ml}$ は 11 製品, $1.3 \mathrm{ml}$ は 1 製品.

今回, 静注用抗菌薬のキット製剤の適切な使用を 支援する目的で，その添付文書に記載された製品情 報の比較検討を行つた.

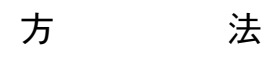

検討の対象とした静注用抗菌薬は本院に採用され ているセフェム系 13 製品, ペニシリン系 5 製品, カルバペネム系 4 製品, 合成抗菌薬 3 製品, グリコ ペプチド系 2 製品及びアミノグリコシド系 5 製品の 計 32 製品とした。

検討した内容はキット製剤の提供の有無, 試験液 の調製法, 試験液及び対照液の皮内投与量, 判定時 間, 判定基準 (陽性, 陰性及び判定不能), 貯法, キット及び実際の製品の使用期限の 7 項目とした. これらの項目はキット及び実際の製品に添付された 文書より調査した.

結果

本院で採用されているすべてのセフェム系, ペニ シリン系及びカルバペネム系抗菌薬の添付文書では 皮膚反応テストを行うことが望ましいと記載されて おり， 22 製品でキットが無償提供されていた。 さ らに, 合成抗菌薬のうちシプロキサン及びグリコ ペプチド系抗菌薬のタゴシッド®の 2 製品は添付文 書に皮膚反応テストを行うことが望ましいと記載 し，同様にキットが無償提供されていた。

キットの試験液の調製法は 24 製品（シプロキサ ン®は溶解済み）で, Table 1 に示すように 5 種類 の方法が記載されていた。 その溶解液は生理食塩 水, 注射用水及び専用溶解液の 3 種類であった. 溶 解液の容量は生理食塩水で $1 \mathrm{ml}$ のアンプル入りが 2 製品, $1.3 \mathrm{ml}$ のアンプル入りが 1 製品, $2 \mathrm{ml}$ のア ンプル入りが 12 製品, 注射用水で $1 \mathrm{ml}$ のアンプル 入りが 4 製品, $2 \mathrm{ml}$ のアンプル入りが 1 製品, 専
用溶解液で $1 \mathrm{ml}$ のアンプル入りが 4 製品であった (Table 1).

試験液及び対照液の皮内投与量はキットの 24 製 品で, $0.02 \mathrm{ml}$ と記載されていた（Table 2).

判定は陽性判定までの時間を 21 製品 (88\%) が 15-20 分後, 1 製品 (4\%) が 15 分後, 2 製品 (8 \%）が 15-30 分後とする基準を記載していた.

陽性判定の基準は，発赤 $>20 \mathrm{~mm}$ ，膨疹>9 mm を 16 製品 $(67 \%)$ を占め, 発赤 $>15 \mathrm{~mm}$, 膨疹>

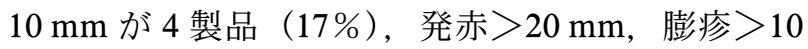
$\mathrm{mm}$ が 3 製品 $(12 \%)$, 発赤 $>20 \mathrm{~mm}$, 膨疹>6 mm が 1 製品（4\%）であった（Table 2).

陰性判定はビクシリン及びビクシリン $\mathrm{S}^{\circledR}$ を除い て, 陽性判定の基準未満と記載されていた。 ビクシ リン®及びビクシリン $\mathrm{S}^{\circledR}$ は陰性判定に独自の基準を 設け，疑陽性の判定基準も記載されていた（Table 2).

キットの貯法は, 温度指定が 11 製品 $\left(25^{\circ} \mathrm{C}\right.$ 以下 が 1 製品, $15^{\circ} \mathrm{C}$ 以下が 2 製品, $10^{\circ} \mathrm{C}$ 以下が 3 製品, $8^{\circ} \mathrm{C}$ 以下が 1 製品, $7^{\circ} \mathrm{C}$ 以下が 1 製品， $2-8^{\circ} \mathrm{C}$ が 2 製品, 冷所が 1 製品), 室温が 13 製品であった (Table 2).

キットは全製品で，外箱に最終年月を表示してい た。さらに，その内の 12 製品は添付文書に有効期 間若しくは使用期限を記載していた。それは 1 年が 3 製品, 1 年 6 力月が 2 製品, 2 年が 5 製品及び 3 年が 2 製品であった（Table 2).

抗生物質製剂自身の使用期限は 2 年が 11 製品, 3 年が 13 製品であった（Table 3).

\section{考察}

抗菌薬の皮膚反応に関して, 米国では問診後に過 敏症の既往がある患者に限って施行されているが, 日本化学療法学会の皮内反応検討特別部会の報告に 


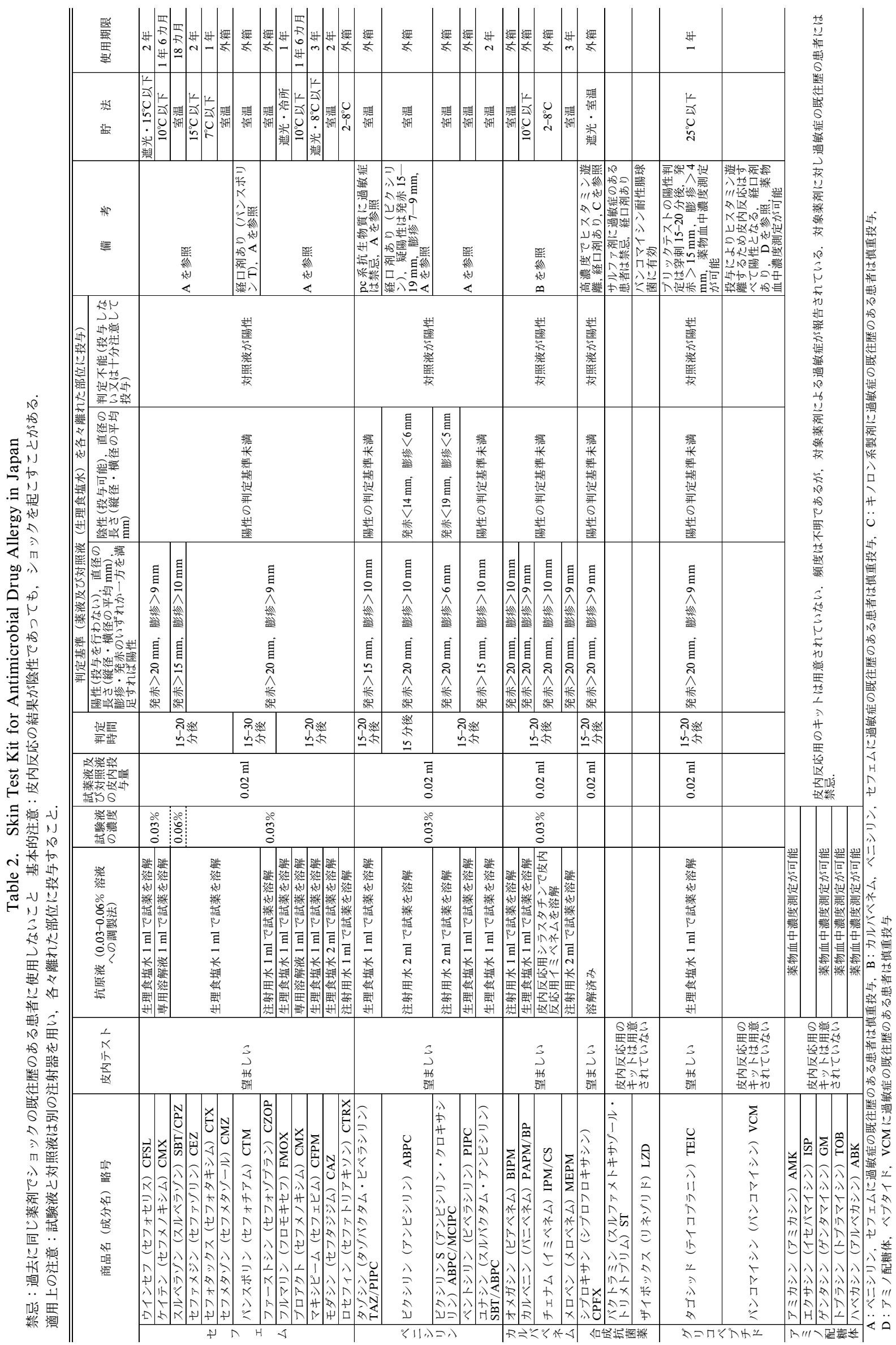


Table 3. Storage Conditions and Intervals to Expiration Antimicrobial Drug

\begin{tabular}{|c|c|c|c|c|c|}
\hline & 商 品 名 & 製造会社 & 貯法 & 使用期限 & $\begin{array}{c}\text { キットと同一 } \\
\text { 使用期限 }\end{array}$ \\
\hline & ウィンセフ & 藤沢薬品工業 & & 2 年 & $\bigcirc$ \\
\hline & ケイテン・ブロアクト & 中外製薬・塩野義製薬 & & 2 年 & \\
\hline & スルペラゾン & ファイザー製薬 & & 3 年 & \\
\hline & セファメジン & 藤沢薬品工業 & & 2 年 & $\bigcirc$ \\
\hline & セフォタックス & 中外製薬 & & 2 年 & \\
\hline フ & セフメタゾン & 三共 & & 2 年 & \\
\hline I & パンスポリン & 武田薬品 & 至温 & 3 年 & \\
\hline & ファーストシン & 武田薬品 & & 2 年 & \\
\hline 公 & フルマリン & 塩野義製薬 & & 2 年 & \\
\hline & マキシピーム & ブリストル & & 3 年 & $\bigcirc$ \\
\hline & モダシン & 日本グラクソ & & 2 年 & $\bigcirc$ \\
\hline & ロセフィン & 日本ロッシュ & & 3 年 & \\
\hline & タゾシン & 富山化学工業 & & 3 年 & \\
\hline ^ْ & ビクシリン & 明治製菓 & & 3 年 & \\
\hline シ & ビクシリン S & 明治製菓 & 室温 & 3 年 & \\
\hline リ & ペントシリン & 三共 ～～～～～～～～ & & 3 年 & \\
\hline & ユナシン & ファイザー製薬 & & 3 年 & \\
\hline 力 & オメガシン & 明治製菓 & & 3 年 & \\
\hline バ & カルベニン & 三共 & 室温 & 2 年 & \\
\hline ペ & チェナム & 万有製薬 & 至温 & 2 年 & \\
\hline $\begin{array}{l}\text { 不 } \\
厶\end{array}$ & メロペン & 住友化学 & & 3 年 & $\bigcirc$ \\
\hline & シプロキサン & バイエル薬品 & & 3 年 & \\
\hline 菌 & バクトラミン & 日本ロッシュ & 室温 & 3 年 & \\
\hline 成薬 & ザイボックス & ファルマシア & & 2 年 & \\
\hline $\begin{array}{l}\text { グペ } \\
\text { リプ }\end{array}$ & タゴシッド & 藤沢薬品工業 & & 3 年 & \\
\hline コド & バンコマイシン & 塩野義製薬 & 至温 & 2 年 & \\
\hline & アミカシン & 万有製薬 & & 3 年 & \\
\hline$\Xi$ & エクサシン & 旭化成 & & 2 年 & \\
\hline 配 & ゲンタシン & シェリングプラウ & 室温 & 2 年 6 力月 & \\
\hline 糖 & トブラシン & 塩野義製薬 & & 2 年 & \\
\hline & ハベカシン & 明治製菓 & & 3 年 & \\
\hline
\end{tabular}

よると, 皮膚反応テストの実施が望ましいとの見解 を示している．また，皮膚科外来における薬疹の原 因薬剤は抗菌薬が半数を占めていることから, 副作 用の既往を問診することは重要である. ${ }^{3)}$ 本邦では 内科及び外科教育施設の多くは, 静注抗菌薬の初回 投与時に皮膚反応テストを行っており, 行い難いと される小児科においてさえも，毎回の実施率が 60 \%と今なお広く施行されている. ${ }^{4)}$ その必要性につ いては議論のあるところではあるが，抗菌薬の添付 文書には重要な基本的注意の事項において, 事前に 皮膚反応を実施することが望ましいと記載されてい る.そのため, 皮膚反応テストの実施は安全性の確 保に加え, 訴訟を考慮した事故対策的な要素の強い
行為である。しかしながら， 2002 年 10 月 24 日付 け中国新聞に報道された皮膚反応テスト陽性の白内 障患者さんに抗菌薬の投与を行った医療過誤は, 不 幸な転帰を迎えている。これらのことから，皮膚反 応テス卜は過去の過敏症の既往の有無を確認する問 診に加えて広く行われている。 しかるに各種の抗菌 薬によって調製や判定方法に差違があり, 臨床の現 場で混乱を招いていることも事実である，米国にお いても, 陽性又は陰性判定の判断が難しいことか ら，薬剤師による皮膚反応テストの実行が試みられ ている. ${ }^{5}$

一方，アナフィラキシーショックを発現しうる抗 菌薬には, セフェム系, ペニシリン系, カルバペネ 
ム系, テトラサイクリン系, ストレプトマイシン, カナマイシン, アンホテリシン $\mathrm{B}$, クロラムフェニ コールなどが知られているが，製造者から製品とは 別に無償で供給されているキットは，セフェム系， ペニシリン系, カルバペネム系と合成抗菌薬のシプ ロキサン®，グリコペプチド系のタゴシッド®のみで ある。

皮膚反応テスト・キットは, セフェム系, ペニシ リン系, カルバペネム系の先発製品のみならず, 後 発品も無償で製造者から提供されており，それらの 添付文書は同一の内容であった。

キットの調製は溶解液あるいはその容量の違いに より 5 種類の溶解方法があるため (Table 2), 施行 する医師を混乱させる要因の 1 つとなつている.さ らに, 抗菌薬を溶解するための液は生理食塩水, 注 射用水及び専用溶解液の 3 種類と多く, 皮膚反応テ ストを施行する医師から, 試験液の調製方法につい て質問が生じることは仕方のない状況である（Table 1).できれば，施行者の混乱を避けるために， 対照液が生理食塩水であることから, 溶解液も特別 な場合を除いて生理食塩水に統一することが望まし いと思われる。

さらに溶解液と対照液を 1 本のアンプルで兼用す る方式は 24 製品中 12 製品, それぞれが独立したア ンプルの方式は 12 製品と調製の方式が 2 種類に別 れており, 溶解から施行に至るまでの作業を複雑化 させている（Table 1).

試験液及び対照液の皮内投与量はすべてのキット で $0.02 \mathrm{ml}$ （薬液濃度： $0.03-0.0375 \%$ ）と記載さ れており (Table 2), 一般的な投与量が選択されて いる. ${ }^{6)}$ 一方, 米国では $0.01-0.02 \mathrm{ml}$ と投与量は柔 軟性を持っている.

局所反応を判定するまでの時間を 21 製品が 15 20 分 $^{-9)}$ とした基準を記載していたが， 1 製品が 15 分, 2 製品が $15-30$ 分 ${ }^{10,11)}$ の基準を記載してい た. 一般的に, 即時型アレルギーは投与後 10-30 分後に出現することが多いとされる. 判定までの統 一した時間は定められていないが，キットの判定時 間が銘柄間で異なることによる混乱を避けるため に，標準化するために一定の時間後，例えば 20 分 ${ }^{12,13)}$ に統一して判断することが適切と思われる.

入手可能であったキットの陽性の判定は, Table に示したように 4 種類の基準が存在する. キットの
$67 \%$ で用いられている膨疹 $9 \mathrm{~mm}$ 以上, 発赤 20 $\mathrm{mm}$ 以上の陽性の判定基準は昭和 38 年に提案され ている. ${ }^{14)}$ 他のキットの判定基準も数ミリ程度で数 值が異なるが，類似した基準であり示された数值の 根拠は明確に示されている訳ではない.9)したがつ て, 最も用いられている澎疹 $9 \mathrm{~mm}$ 以上，発赤 20 $\mathrm{mm}$ 以上で陽性の判定を行う基準を標準として用い れば，混乱もなく効率的であると考えられた。陰性 の判定基準は陽性の判定基準未満とした記載が多い が, 3 種の基準が記載されていた。 ビクシリン ${ }^{\circledR}$ 独自の判定基準を設けているため, 疑陽性という判 定が存在する。疑陽性（膨疹 7-9 mm, 発赤 15$19 \mathrm{~mm}$ ）は曖昧な判定基準であり，投与可能か否か が不明確である。これは，アンピシリンの皮内反応 による過敏症の発現を多施設で検討した研究におい て, 疑陽性の判定基準が設定されていることが原因

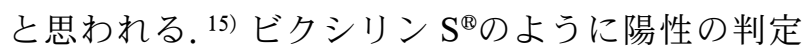
基準未満とするほうが理解し易いと思われた.

通常，対照液は試験液とほぼ同時に皮内に注射し て, 判定の対照として用いる. しかしながら, 複数 の皮膚反応テストを行う場合, 患者の肉体的負担は 大きい. 皮膚反応テストの信頼性がはっきりしない 現状では, 試験液を最初に投与して結果が陰性であ れば, 対照液の投与を省略する方法も考慮する必要 がある。ささらに, 皮膚反応テストの医療経済性を検 討した報告は，同様に陽性反応を示したときのみに 対照液の投与を行うことにより, 医療材料費を軽減 できるとしている. ${ }^{16)}$

キットの貯法は温度指定が 12 製品, 室温が 12 製 品であった（Table 1).

その指定温度は $25^{\circ} \mathrm{C}$ 以下, $15^{\circ} \mathrm{C}$ 以下, $10^{\circ} \mathrm{C}$ 以下, $8^{\circ} \mathrm{C}$ 以下, $7^{\circ} \mathrm{C}$ 以下, $2-8^{\circ} \mathrm{C}$, 冷所の 7 種類で, こ れらは冷蔵庫での保管を示唆するものである。しか しながら，これら貯法温度の指定されたキットの実 際の製品本体は室温保存であった。 キットに含まれ る微量の抗菌薬の安定性は明らかにされていない が，例えばフルマリンの場合，インタビューフ オームでは $25^{\circ} \mathrm{C} て ゙ 27$ 月間は規格内にあるとされ る. 一方，フルマリンのキットは冷所に保管した 場合, 使用期限は 1 年となっている. 病棟詰め所あ るいは薬局の限られた冷蔵スペースの中で, 各銘柄 のキットの保管は負担となる場合が多い. 第 14 改 正日本薬局方によれば，室温は $1-30^{\circ} \mathrm{C}$ と規定され 
ている. したがって, キットの貯法に温度の指定が 行われているが, 室温が $30^{\circ} \mathrm{C}$ を超えない状況であ れば, 室温保存は可能かと思われる.

すべてのキットは外箱に使用期限を表示し，一部 であるが添付文書に製造後 1 年から 3 年の有効期間 を表示した製品が認められた。実際の製品と同一の 使用期限のキットは 5 製品あるが, 使用期限の短い 製品若しくは期限が明らかでないキットもある. 貯 法が冷所であるフルマリン ${ }^{\circledR}$, タゴシッド 及びセフ オタックス ${ }^{\circledR}$ は有効期間が製造後 1 年と短く設定さ れており，使用期限の管理に注意が必要である.

塩野義製薬 (株)の内部資料によると, フルマリ ンのキットは $15^{\circ} \mathrm{C}$, 遮光保存で 12 力月で $83.9 \%$ と力価の低下するロットが認められたことから, 使 用期限を 1 年としている. 低下の理由としてフルマ リン®の製品は, 安定剤である塩化ナトリウムを含 有しているが，キットはそうでないことが一因とし て考えられる.また, 藤沢薬品工業 (株)の内部資料 によると, タゴシッド®のキットは安定性試験を 15 カ月までしか行っていないことから, 使用期限を 1 年としている場合もある. 中外製薬(株)の内部資料 によると, セフォタックス ${ }^{\circledR}$ のットは $5^{\circ} \mathrm{C}, 15$ 力月 間で 94.6\%と力価の低下すること, 経時的に $\mathrm{pH}$ の 低下することが認められたことから，使用期限を 1 年としていた。製薬会社は独自の基準を設けて使用 期限を設定しているが，できれば実際の製品とキッ 卜は同じ使用期限になることが望ましいと思われる.

以上, 抗菌薬の皮膚反応テストの調製法, 判定基 準, 貯法などについて考察した. 皮膚反応テストの 陽性判定基準の統一及び調製法の簡略化は，施行者 の混乱を避けるために望まれる.さらに, 皮膚反応 テストにより得られた結果が抗菌薬の安全な投与に 反映されるためには，その情報をメディカルスタッ フ間で共有できるように，カルテなどに貼付できる シールをキットに添付する必要もある.

\section{REFERENCES}

1) Saito A. et al., Jpn. J. Chemothe., 50, 95-96 (2002).

2) Nipponijishinpo, No. 2950, 114 (1980).

3) KimKea J., Environm. Derma., 5, 49-57 (1998).

4) Kamekou A., Nikkei Medical, 8, 26-27 (2002).

5) Clyne K. E., Ternes R. L., Am. J. Health Syst. Pharm., 53, 2062-2067, (1996).

6) Takemoto I., Awaya T., Akutsu S., Inagaki S., Touyomaeni kabinsho-test wo yosuruyakuzai, Iyakujournal-sha, Osaka, 1990, pp. 9-21.

7) Hino H., Scratch test, skinreaction, HihukaMOOK, Kinbarashuppan, Tokyo, 1989, pp. 29-34.

8) Iwamoto I., Sano H., J. Jpn. Soc. Hosp. Pharm., 29, 1089-1091 (1994).

9) Ito K., Rinshoui, 9, 644-648 (1983).

10) Toshitani S., Hayashi N., Rinshotokenkyu, 59, 1427-1432 (1983).

11) Aihara M., Osawa J., Saito S., Ikezawa Y., J. Jpn. Soc. Hosp. Pharm., 28, 19-23 (1993).

12) Romano A., Mayorga C., Torres M. J., Artesani M. C., Suau R., Sanchez F., Perez E., Venuti A., Blanca M., J. Allergy Clin. Immunol., 106, 1177-1183, (2000) .

13) Blanca M., Torres M. J., Garcia J. J., Romano A., Mayorga C., Ramon E., Vega J. M., Miranda A., Juarez C., J. Allergy Clin. Immunol., 103, 918-924, (1999).

14) Ishizaki T., J. Jpn. Med. Assoc., 62, 761-772 (1969).

15) Fukuyama K., Nakashima H., Adachi M., Katsube S., Kondo K., Rinshoutokenkyu, 53, 550-557 (1976).

16) Itagaki T., Kagakuryouhounoryouiki, 13, 1568-1569 (1997). 